\title{
СВІТЛОЇ ПАМ'ЯТІ ПРОФЕСОРА АНТОНІНИ ОЛЕКСІЇВНИ РУДЕНКО
}

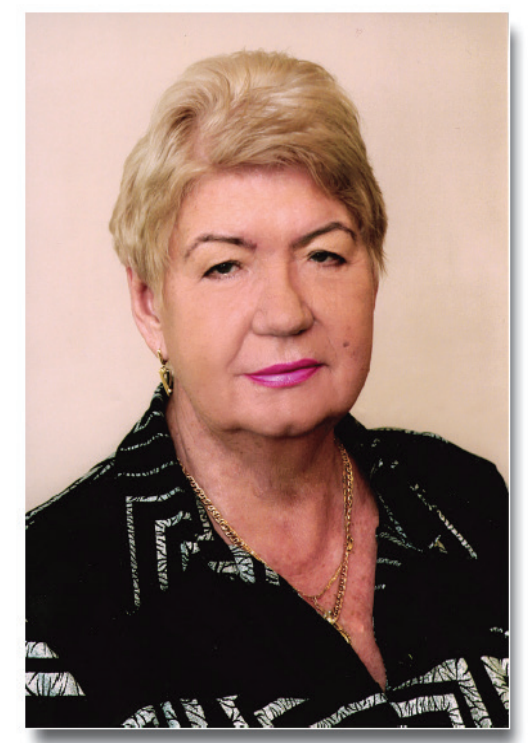

На 84-му році життя відійшла у вічність відома українська вчена, інфрекціоністка, Заслужена лікарка України, кавалер відзнаки НАМН України «Знак пошани», доктор медичних наук, професорка Антоніна Олексіївна Руденко. Висвітлено ії основні біографрічні віхи та творчі досягнення.

10 серпня 2020 р. пішла з життя відома українська вчена, інфекціоністка, Заслужена лікарка України, кавалер відзнаки НАМН України «Знак пошани», доктор медичних наук, профресорка Антоніна Олексіївна Руденко.

А.О. Руденко народилась 06.12.1936 р. у м. Дніпропетровську. У 1951 р., у 15 років, вступила, а у 1954 р. закінчила Київську школу (медичне училище) медичних сестер, після чого з 1954 по 1957 рр. працювала за призначенням медичною сестрою в лікарні №1 м. Києва.

У 1963 р. отримала диплом лікаря. Трудову діяльність Антоніна Олексіївна розпочала в селі Веселинівка Переяслав-Хмельницького району Київської області, де очолила дільничну лікарню. Потім у 1964-1969 рр. працювала у лікарні № 10 Московського району м. Києва.

Творча вдача та зацікавленість інфекційними хворобами привела Антоніну Олексіївну до Київського НДІ інсрекційних хвороб МОЗ України, і у 1969 р. вона була прийнята на посаду молодшого наукового співробітника відділу грипу та гострих респіраторних захворювань. У 1979 р. вона захистила кандидатську дисертацію, у 1989 р. - докторську дисертацію, а у 2006 р. їй було присвоєно вчене звання профресора.

31990 р. Антоніна Олексіївна була беззмінним завідувачем відділу нейроінфекцій Інституту - натепер ДУ «Інститут епідеміології та інфекційних хвороб ім. Л.В. Громашевського НАМН України».

Своє життя Антоніна Олексіївна присвятила боротьбі з інфекційними хворобами людини. Нею зроблений значний внесок у розвиток інфектології, створення вітчизняної школи іноекціоністів, розробку, впровадження стандартів діагностично-лікувального процесу та стаціонарної допомоги інсекційним хворим і Державних соціальних стандартів України з наданням медичної допомоги інфекційним хворим в амбулаторно-поліклінічних умовах. Окремим напрямком діяльності А.О. Руденко було вивчення патогенетичних механізмів розвитку легеневих ускладнень при грипі та інших гострих респіраторних захворюваннях, уражень нервової системи вірусної, у тому числі герпетичної, вірусно-бактерійної і бактерійної природи, фрормування затяжного та рецидивного їх перебігу; удосконаленню лікування та профрілактики їх несприятливих наслідків.

Результати наукової діяльності та багаторічний досвід практикуючого лікаря А.О. Руденко знайшли відображення у значній кількості нормативних й інструктивних документів Кабінету Міністрів та МОЗ України.

Антоніна Олексіївна була автором 367 наукових праць. Готувала наукові кадри, багаторазово виступала рецензентом та опонентом кандидатських і докторських дисертаційних робіт, надаючи суттєву допомогу їх виконавцям.

Впродовж 1992-2004 рр. А.О. Руденко була головним позаштатним інфекціоністом Міністерства охорони здоров'я України, віддаючи багато сил і часу організації боротьби 3 іноекційними хворобами: особисто виїжджала на спалахи, брала безпосередню участь в їх ліквідації, активно впроваджувала нові методи лікування, діагностики та профілактики у практику інсрекційної служби країни. Була членом центральної Атестаційної комісії та численних комісій, робочих груп при МОЗ України; членом редколегії журналів «Інфекційні хвороби», «Сучасні інфекції», «Профрілактична медицина»; протягом багатьох років була членом вченої ради дУ «Інститут епідеміології та інорекційних хвороб ім. Л.В. Громашевського НАМН України» та спеціалізованої 


\section{ЮВІЛЕї ТА ПОДії}

вченої ради із захисту кандидатських і докторських дисертацій. 32007 р. очолювала наукове товариство інфекціоністів м. Києва й області.

За внесок у боротьбу з інфекційними хворобами А.О. Руденко неодноразово отримувала почесні державні відзнаки УРСР, почесні грамоти НАМН України, нагороджена почесним званням «Заслужений лікар України». У жовтні 2016 р. Антоніна Олексіївна однією з перших у галузі була нагороджена почесною відзнакою НАМН України «Знак пошани».

Антоніна Олексіївна Руденко назавжди залишиться у нашій пам'яті красивою, привітною, доброзичливою жінкою, яка викликала глибоку повагу та любов колег і пацієнтів.

Світла пам'ять Антоніні Олексіївні.

Колектив Інституту епідеміології та інфекційних хвороб ім. Л.В. Громашевського НАМН України, президія ГО «Всеукраїнська асоціація інфрекціоністів», редакція журналу «Інфрекційні хвороби», учні, колеги, друзі.

\section{CHERISHED MEMORY OF PROFESSOR ANTONINA OLEKSIYIVNA RUDENKO}

SUMMARY. At the age of 84, the famous Ukrainian scientist, infectious disease specialist, Honored Doctor of Ukraine, holder of the "Badge of Honor" of the National Academy of Medical Sciences of Ukraine, Doctor of Medical Sciences, Professor Antonina Rudenko passed away. Her main biographical milestones and creative achievements are highlighted.

Конфрлікту інтересів немає.

The authors have no conflicts of interest to declare. Отримано 18.08.2020 p. 